\title{
Measuring Individual Economic Well-Being and Social Welfare within the Framework of the System of National Accounts
}

\section{Citation}

Jorgenson, Dale W., and Paul Schreyer. 2017. Measuring Individual Economic Well\#Being and Social Welfare within the Framework of the System of National Accounts. Review of Income and Wealth 63, no. S2: S460-477.

\section{Permanent link}

http://nrs.harvard.edu/urn-3:HUL.InstRepos:41718757

\section{Terms of Use}

This article was downloaded from Harvard University's DASH repository, and is made available under the terms and conditions applicable to Open Access Policy Articles, as set forth at http:// nrs.harvard.edu/urn-3:HUL.InstRepos:dash.current.terms-of-use\#OAP

\section{Share Your Story}

The Harvard community has made this article openly available. Please share how this access benefits you. Submit a story. 


\title{
Measuring Individual Economic Well-Being and Social Welfare within the Framework of the System of National Accounts
}

Keywords: Welfare measurement, national accounts, distribution of consumption

JEL:

E210, D31, D63

\begin{abstract}
While the agenda of "beyond GDP" encompasses measurements that lie outside boundaries of the System of National Accounts, key aspects of individual well-being and social welfare can be incorporated into an SNA framework. We bring together the relevant theoretical literature and the empirical tools needed for this purpose. We show how consumption-based measures of economic welfare can be integrated into the national accounts without changing their production or asset boundary. At the same time, explicit normative and methodological choices are required to select a social welfare function. The paper provides guidance how to make these choices transparent and how to present social welfare measures.
\end{abstract}




\section{Introduction}

Renewed interest in the measurement of individual well-being and social welfare is evident in the recommendations by Stiglitz, Sen, and Fitoussi (2010) on the measurement of economic performance and social progress and the G20 Data Gaps Initiative (2009) on enhancements in economic and financial statistics. While the agenda of "beyond GDP" encompasses measurements that lie outside the production and asset boundaries of The System of National Accounts 2008 (2009), key aspects of individual well-being and social welfare can be incorporated into the framework of the SNA 2008. A leading example is the measures of individual and social welfare proposed by Jorgenson and Slesnick (2014).

The common features of the Stiglitz-Sen-Fitoussi and Data Gaps reports are a focus on income, consumption and wealth, rather than production, and an emphasis on disparities among members of the population rather than national aggregates. In response to the interest in income, consumption/saving, and wealth, the OECD and Eurostat established an Expert Group on Disparities in a National Accounts framework (EG DNA) to consider standards for the measurement of disparities within the framework of the national accounts. A second OECDEurostat Expert Group on Income, Consumption and Wealth (EG ICW) considered consistency between definitions of these concepts in macro-economic data from the national accounts and micro-economic data from household surveys and administrative records. Initial results have been reported by Fesseau, Wolff, and Mattonetti (2013) and Fesseau and Mattonetti (2013). 
The expert group on disparities has collected information from leading statistical agencies on the role of distributional information in the national accounts and existing capabilities for providing the necessary survey information. The expert group has discussed the reconciliation of national accounting aggregates with survey statistics and have given detailed empirical examples of methods for incorporation of these statistics into the 2008 SNA. Our work embeds these statistical advances in a broader theoretical framework based on Jorgenson and Slesnick (2014) and proposes measures of individual economic well-being as well as summary measures of social welfare.

The measurement of individual economic well-being is based on a long-established theory of consumer behaviour.1 This is useful in choosing among the many possible approaches to the measurement of consumption considered in the literature and could be helpful in extending these approaches beyond the boundaries of the 2008 SNA, which we do not consider in this paper. The first issue is the definition of the consumption unit. In economic surveys consumption is measured for households, consisting of individuals living together and sharing a budget. While the theory of consumer behaviour deals with the individuals, rather than households, there is also a wellestablished, if less familiar, theory of household behaviour that can serve as a valuable guide to the measurement of consumption.

We thus take the household, rather than the individual, as the starting point for the measurement of consumption at the micro-economic level. This results in a second issue for economic statistics, namely, that a large household requires more measured consumption than a small household to achieve the same level of well-being. However, such differences are not

\footnotetext{
1The year 2015 is the centennial of Eugen (Evgeny) Slutsky (1915), "Sulla theoria del bilancio del consumatore," Giornale degli Economisti, 51(3): 1-26, often taken as the starting point for the theory of consumer behaviour.
} 
necessarily proportional to household size. In measuring disparities among consuming units economic statisticians have introduced household equivalence scales to capture differences in the composition of households. At a minimum these scales depend on the number of individuals, but Jorgenson and Slesnick (1987) have shown how to use an econometric model of household behaviour to derive equivalence scales that depend on other characteristics of household composition as well. We compare the effect of using a uni-dimensional, size-related household scale with the Jorgenson-Slesnick multi-dimensional household scale and find important differences with likely effects on measured living standards.

In this paper we consider the measurement of individual welfare in Section 2. By way of example, we use information from the U.S. consumer expenditure survey and control totals from the national accounts to construct measures of individual well-being. These measures incorporate differences in prices and total expenditure along with information about household composition. The distribution of individual welfare over a given population provides the information required to quantify differences among households. These are the "disparities" of EG DNA and can be integrated into the national accounts along with accounting aggregates like consumer expenditures. It is useful to emphasize that consumer expenditures could be augmented in various ways, recently summarized by Abraham (2014), but this would involve changing the boundaries of the national accounts.

The measurement of social welfare is based on the economic theory of social choice. This provides a framework useful in choosing among the many approaches for measuring social welfare considered in the literature. Measures of social welfare are based on the distribution of consumption scaled by a measure of household size. We refer to this as the distribution of 
household equivalent consumption.2 While measures of individual welfare depend on optimization by households, no optimization is involved in deriving measures of social welfare from the theory of social choice. However, by contrast with measures of individual welfare, social welfare measures depend on normative assumptions or value judgements. Jorgenson and Slesnick (2014) have shown how to incorporate these normative assumptions into measures of social welfare within the framework of the national accounts. We discuss some of the properties of the Jorgenson-Slesnick social welfare measure and compare them with the welfare measure proposed by Atkinson (1970).

We also refer to a measure of social welfare as the standard of living. We consider only those measures of the standard of living that are feasible, given information about individual welfare available within the framework of the national accounts. Following Atkinson (1970), we decompose measures of social welfare between measures of efficiency and equity. Measures of equity can be transformed into measures of inequity or inequality. Our measures of efficiency can be expressed in terms of national accounting aggregates in particular real personal consumption expenditure per household equivalent member.

In Section 4 we conclude that economic statisticians should use measures of social welfare, including efficiency and equity, to summarize information about the distribution of individual welfare. We emphasize that this can be done within the 2008 SNA. Fortunately, the practical issues that confront statistical agencies in measuring individual well-being and social welfare have been discussed exhaustively by EG ICW and EG DNA.

\footnotetext{
2 The term "equivalised consumption" is sometimes used for scaled household consumption, but "household equivalent consumption" conveys the same meaning and is closer to standard English usage.
} 


\section{Measures of individual economic well-being}

\section{Whose well-being? Households, individuals and equivalence scales}

Our investigation starts at the micro-economic level with a question about the nature of the consuming unit. The key lies in the distinction between households and individuals. Although the traditional theory of consumer behaviour is based on individuals, more in-depth analysis has recognised that the household is a more appealing way to think about decision-making units. The necessary framework was provided by the theory of household behaviour of Samuelson (1956).3 Our starting point for welfare comparisons is thus the household. This coincides with the fact that empirical sources of information on consumption or income are typically collected for households, not individuals. At the same time, households may have quite different characteristics, for example in terms of the number of individuals living in a household so it is not obvious whether one household's economic well-being can be directly compared to another household's well-being unless they share the same characteristics.

The single most frequently used characteristic is household size. The Canberra Group Handbook on Household Income Statistics describes this as follows: " [...] the needs of a household grow with each additional member but, due to economies of scale in consumption, not in a proportional way. For example, a household comprising three people would normally need more income than a lone person household if the two households are to enjoy the same standard of living. However, a household with three members is unlikely to need three times the housing space, electricity, etc. that a lone person household requires.” (UN-ECE 2011, p. 68)

"Equivalised consumption or income is an indicator for welfare comparisons across standardised households or for a household comprising more than one person, equivalised income

\footnotetext{
3 Samuelson's theory has been discussed by Becker (1981) and Pollak (1981).
} 
is an indicator of the household income that would be needed by a lone person household to enjoy the same level of economic welfare as the household in question.” (UN-ECE 2011, p. 68)

An example of such a simplified approach is the OECD modified equivalence scale (Hagenaars et al. 1994), commonly used in statistical work. Within each household, the first adult counts 1 , all children under 14 get a weight of 0.3 and any additional person aged 14 and above gets a weight of 0.5 . The original 'OECD equivalence scale' (OECD 1982, also called "Oxford scale") assigned a value of 1 to the first household member, of 0.7 to each additional adult and of 0.5 to each child. Recent OECD publications (e.g. OECD 2011, OECD 2008) comparing income inequality and poverty across countries have used a scale which divides household income by the square root of household size.

The economic theory of equivalence scales (see Lewbel and Pendakur 2008 for an overview) takes a more general starting point and defines equivalence scales as the proportional change in expenditure that is required to equalise utility between two households with different characteristics. In this vein, Barten (1964) proposed an approach where equivalence scales varied across types of commodities. As these equivalence scales depend on expenditure patterns, they vary not only with household size but also with prices and household characteristics that shape expenditure patterns. As a consequence, equivalence scales become multi-dimensional. Muellbauer (1977) estimated Barten scales for the United Kingdom, Johnson (1994) and Slesnick and Jorgenson and Slesnick $(1987,2014)$ estimated Barten scales for the United States. Table 1 reproduces Barten scales estimated by Jorgenson and Slesnick (1987). 
Table 1. Barten equivalence scales*

\begin{tabular}{c|c|c|c|c|c|c}
\hline & & & & & & \\
\hline Size 1 & Size 2 & Size 3 & Size 4 & Size 5 & Size 6 & Size 7+ \\
\hline 0.32 & 0.57 & 0.76 & 1 & 1.11 & 1.52 & 1.92 \\
\hline Age 16-24 & Age 25-34 & Age 35-44 & Age 45-54 & Age 55-64 & Age 65+ & \\
\hline 0.65 & 1 & 1.39 & 1.53 & 1.39 & 0.93 & \\
\hline Northeast & Midwest & South & West & Nonfarm & Farm & \\
\hline 1 & 1.03 & 1.13 & 0.74 & 1 & 1.63 & \\
\hline White & Nonwhite & Male & Female & & & \\
\hline 1 & 1.12 & 1 & 0.62 & & & \\
\hline & & & & & & \\
\hline
\end{tabular}

*Reference household: size 4, age 25-34, Northeast, nonfarm, white, male.

Source: Slesnick (1991), based on Jorgenson and Slesnick (1987).

Establishing Barten scales requires, however, estimation of a system of consumer demand to evaluate how expenditure patterns change with household characteristics and with prices. This is a tall order and will often be impractical for statistical offices to implement. In practice, thus, equivalence scales will often be uni-dimensional (household size only) and independent of prices and expenditure patterns. Even so, the choice remains large and there is no obvious best way to adjust for household size. Table 2 compares different equivalence scales and their average elasticity with respect to household size. Differences are significant and can affect results of overall welfare measures. There is no single best equivalence scale and statistical offices have to balance the advantages of uni-dimensional scales (simplicity) against greater realism but also greater complexity of Barten-type scales. 
Table 2. Different equivalence scales

\begin{tabular}{|r|r|r|r|r|}
\hline $\begin{array}{c}\text { Household } \\
\text { size }\end{array}$ & $\begin{array}{c}\text { Per } \\
\text { capita } \\
\text { measure }\end{array}$ & $\begin{array}{c}\text { Barten } \\
\text { scale (size } \\
\text { dimension } \\
\text { only) }\end{array}$ & $\begin{array}{c}\text { OECD } \\
\text { (old) }\end{array}$ & $\begin{array}{c}\text { OECD } \\
\text { (square } \\
\text { root } \\
\text { formula) }\end{array}$ \\
\hline 1 & 1.00 & 1.00 & 1.00 & 1.00 \\
\hline 2 & 1.00 & 0.83 & 0.77 & 0.50 \\
\hline 3 & 1.00 & 0.79 & 0.72 & 0.50 \\
\hline 4 & 1.00 & 0.82 & 0.72 & 0.50 \\
\hline 5 & 1.00 & 0.77 & 0.72 & 0.50 \\
\hline 6 & 1.00 & 0.87 & 0.73 & 0.50 \\
\hline 7 & 1.00 & 0.92 & 0.74 & 0.50 \\
\hline
\end{tabular}

Another, related measurement issue is the level of detail at which distributional measures are put in place. Ideally, the equivalence scales are directly applied to household-level information. In practice, another simplifying assumption is often used in empirical measurements. Rather than applying equivalence scales (and, as will be discussed below, price indices) at the level of individual households, groups of households are the object of measurement in the simplified case. Each group is treated like a single, homogenous household. A natural way of grouping individual households is forming quintiles or deciles based on households' consumption or income. For instance, results of the U.S. consumer expenditure survey are published by quintiles defined over primary income of households. Jorgenson and Slesnick $(1987,2014)$ allow for a much more granular treatment of households - grouping and the scaling of consumer expenditure take place for individual households with identical demographic characteristics.

\section{Whose price index? Recognising differences in expenditure structures}

Much of the literature on the distribution of income or consumption has focused on how these attributes are distributed among agents at a point in time but has paid less attention on how to render group-specific income or consumption comparable both between households and over 
time. The conceptually correct measure of price changes is a cost-of-living index (Konüs 1929). As households with different levels of consumption or income will feature different expenditure patterns, their cost-of-living indexes will in general be different and consequently, deflation of nominal consumption or income should proceed by means of a group-specific price index.

Separate cost of living indices for groups of households can be constructed as long as there is information on expenditure patterns for each type of household. If no such possibility exists, a rather strong assumption has to be invoked, namely that preferences of a household only depend on relative prices but are otherwise independent of the level of household welfare 4 which may only affect the level of expenditures in a proportional way. The advantage of this simplification is that a single price index can be applied to deflate consumption or income for all households.

However, this trade-off appears to be of limited effects when examined empirically. Slesnick (2001) computes cost-of-living indices for household groups with different consumption levels for the time period 1948- 1995 and concludes that “...the inflation rates for the three groups are [...] very similar" (p. 84). In our own empirical example based on recent data from the U.S. Consumer Expenditure Survey we construct a set of expenditure weights for each product group, household group and year under consideration. Weights from adjacent years are combined with the price changes for each product group to construct a Fisher price index of final household consumption expenditure by household income quintile. For the period 2005-2013 differences between price indices for the five groups of households are small, ranging between $1.9 \%$ and $2.1 \%$ per year. The

\footnotetext{
4 Independence from welfare levels implies homotheticity - a necessary and sufficient condition for the independence of the price index from the level utility, as shown by Malmquist (1953).
} 
use of an aggregate price index for different consumption groups would thus not appear to be a specifically constraining assumption 5 .

Even if a single price index is chosen for different households, there are several choices, for example the private consumption deflator from the national accounts, and various variants of the Consumer Price Index (CPI). Meyer and Sullivan (2011) and Broda and Weinstein (2009) show the important impact of alternative price indices. Fixler and Johnson (2014) opt for the Personal Consumption Expenditures (PCE) deflator on the grounds that their work focuses on a national accounts-based measure of income and its distribution. The same reasoning applies to the calculations at hand where consumption expenditure for the various product groups will be deflated with price indices from the national accounts. We conclude that applying the deflator for private consumption expenditure from the national accounts constitutes a reasonable method to derive measures of real consumption.

\section{A measure of households' economic well-being}

Having dealt with equivalence scales, deflation and the scope of consumption, we can now explicitly state a measure $\mathrm{W}_{\mathrm{k}}$ of individual welfare for household $\mathrm{k}(\mathrm{k}=1, \ldots \mathrm{K})$ :

$$
\mathrm{W}_{\mathrm{k}}=\mathrm{W}_{\mathrm{k}}\left(\mathrm{V}_{\mathrm{k}}\right) \text { with } \mathrm{V}_{\mathrm{k}}=\frac{\mathrm{p} \cdot \mathrm{x}_{\mathrm{k}}}{\mathrm{m}_{0}\left(\mathrm{~A}_{\mathrm{k}}\right) \mathrm{G}_{\mathrm{k}}(\mathrm{p})}
$$

In (1), $\mathrm{p}$ is a vector of $\mathrm{N}$ prices of consumer products and $\mathrm{xk}$ is a vector of $\mathrm{N}$ quantities of products consumed by household $\mathrm{k}$. Real consumption per household equivalent member $\mathrm{V}_{\mathrm{k}}$ is derived by deflating the nominal value of expenditure $\mathrm{p} \cdot \mathrm{xk}_{\mathrm{k}} \equiv \sum_{\mathrm{i}} \mathrm{p}_{\mathrm{iX}} \mathrm{i}, \mathrm{k}$ by a household-specific price index $\mathrm{G}_{\mathrm{k}}(\mathrm{p})$

\footnotetext{
5 Note that this conclusion is based on a single characteristic, income, to group households and measure their cost-ofliving index. Differentiation by other characteristics, in particular age, has been shown to yield more diverse results (Slesnick 2001). Thus, with more complete information, for instance from econometric measurement that permits identifying expenditure patterns across multiple dimensions one may well find more pronounced differences between price indices for different groups of households.
} 
or, in a simplified approach, by a general price index $G(p)$. Real consumption per household is then transformed into consumption per household equivalent member by applying an equivalence scale mo(Ak) corresponding to household k's characteristics $A_{k}$. As discussed earlier, in the simplest case this is a function of household size only but in general captures multiple household characteristics.

The scope and valuation of the products entering a household's utility function are captured by private consumption expenditure here. The implication is that those goods and services that are provided for free by the government will not be captured by this expenditure measure despite the fact that they generate utility for the household. Or they will be valued at a price below cost in the case of subsidisation. An alternative would thus be to select a measure of Actual Individual Consumption that includes Social Transfers in Kind, such as free health care, education or housing. However, prices and volumes of a measure of actual individual consumption do not reflect the consumer decisions in the face of a set of prices. Also, data availability is significantly more limited. The expenditure framework used is best understood as cost-minimising behaviour on the side of consumers, conditional on a set of publicly-provided services.

Jorgenson and Slesnick $(1984,2014)$ set $\mathrm{W}_{\mathrm{k}}$ as the logarithmic transformation measure of the real expenditure measure $\mathrm{V}_{\mathrm{k}},\left(\mathrm{W}_{\mathrm{k}}=\ln \left(\mathrm{V}_{\mathrm{k}}\right)\right)$ implying that utility gains are decreasing with increasing consumption. In a more complete setting such as Jorgenson and Slesnick $(1984,2014)$ the individual measure of welfare is derived as a household's minimum expenditure to achieve a particular level of utility, $W_{k}$, given prices $p . V_{k}\left(W_{k}, A_{k}, p\right)$ then equals the household's expenditure function which provides an exact representation of the underlying level of the household's utility 6.

\footnotetext{
6 In the present framework, utility only depends on the level of consumption and household characteristics. Outside the framework of the national accounts, household utility could also depend on factors such as the health of
} 


\section{Which consumption? Which income? From surveys to the national accounts}

An underlying premise to this point has been that consumer expenditure or income, and prices and quantities of consumer products are readily observable for each household or group of households. This is not a matter of course when national accounts definitions of consumption and income are used as the benchmark or target definitions (Deaton 2005). Yet, taking national accounts benchmarks is a necessary step to derive national accounts-consistent welfare comparisons that can be compared with other national accounts variables such as GDP per capita. The national accounts framework is particularly useful as it provides a consistent link between primary and disposable income, consumption, savings and wealth.

In many instances national accounts estimates may be expected to be of higher quality than those from micro-sources due to the focus of national accounts on consistent and exhaustive estimates (Fesseau and Mattonetti 2013). The big disadvantage of national accounts data in the present context is that distributional information - essential for measures of economic well-being - is missing. Statistical groundwork is therefore required to use the informational contents from survey information about distributions of consumption or income across households and apply it to national accounts benchmarks. This cannot be done in an indiscriminate manner and requires careful comparison of definitions and contents of income and consumption categories in surveys and in national accounts.

Fixler and Johnson (2014) report on early estimates by Budd and Radner (1975) who combine survey and tax data sources to construct a distributional measure for the national accounts. Fesseau, Bellamy and Raynaud (2009) use survey data combined with other statistical

household members, environmental quality or social relations. While the latter factors are clearly important, we leave these non-market variables aside here and focus on economic well-being. For an extension to non-market variables see Fleurbaey and Blanchet (2013). 
sources to develop a national accounts compatible distribution statistic for France. This work was brought to the international level by the OECD and Eurostat in 2013. In cooperation with 25 national statistical offices, survey-based information on the level and distribution of consumption and income categories were matched to the national accounts, following a common methodology. The various steps involved along with results for a recent year are described in Fesseau and Mattonetti (2013).

As the authors note, the introduction of national accounts concepts is not innocuous: inequality measures such as the ratio of income or consumption of the richest over the poorest quintile of households tend to be adjusted downwards when compared to survey-based measures. At the same time, this effect depends on the specific choice of income or consumption variables. One such choice is between final consumption expenditure and actual individual consumption: the latter includes social transfers in kind, i.e., health, education and housing services provided for free or at a below-market price by the government. As these services tend to be disproportionally used by low-income households, inequality measures based on actual individual consumption tend to turn out lower than inequality measures based on final consumption expenditure7.

Similarly, Fixler and Johnson (2014) present a methodology that adjusts the U.S. Current Population Survey - a household survey - to more closely match the national accounts measure of personal income. The authors then complement the survey source with data from tax returns to obtain more granular information on income distribution and apply this to the national accounts

7 A similar reasoning applies to income-based measures of inequality: those based on adjusted disposable income (which reflects social transfers in kind) tend to produce lower levels of inequality than those based on disposable income or those based on primary income. 
benchmarks of disposable household income. Like Fesseau and Mattonetti (2013), a further step by the authors consists in imputing values for social transfers in kind.

Our simplified example uses results from the U.S. Consumer Expenditure Survey as conducted and published by the U.S. Bureau of Labor Statistics. We match 15 expenditure categories to the expenditure categories available in the OECD's Annual National Accounts database 8 (Table 3). Clearly, this is a much rougher approximation than the match by Fesseau and Mattonetti (2013) or Fixler and Johnson (2014) but it serves the purpose of demonstrating feasibility of proceeding in this direction. The advantage of our approach is that it can readily be applied to several years and we shall present results for the period 2005-2013.

Table 3 shows only the mapping between expenditure categories and adjustment coefficients for 2013 but the figures are representative for other years as well. For the majority of categories, the national accounts figure exceeds the figure from the Consumer Expenditure Survey. An important step in national accounts-based computations of individual and social welfare consists thus of matching consumer expenditure data for each product category and quintile of households between survey and national accounts sources. For consumption categories that are not present in

\footnotetext{
8 The consumer expenditure survey provides expenditures for each category cross-classified by household income group. Thus, for every income group, the survey-based expenditure measure is multiplied by the adjustment factor to arrive at the relevant variable $V_{k}$ for household (income group) $k$. If there is added information about the distribution across income groups of those national accounts expenditure positions that are outside the survey measure, this information can of course be used and adjustment factors would vary across income groups. The consumer expenditure survey also provides information of the average household size for each income group. To this information is applied an equivalence scale so to obtain the average number of household equivalent members per income quintile. Averaging across income groups (as these are quintiles with equal numbers of households each a simple average suffices) and multiplying by the economy-wide number of households yields the total household equivalent members.
} 
survey data such as FISIM or, in some cases, the value of owner-occupied housing, an imputation will be required drawing on additional sources.

Table 3. Simplified mapping of product categories

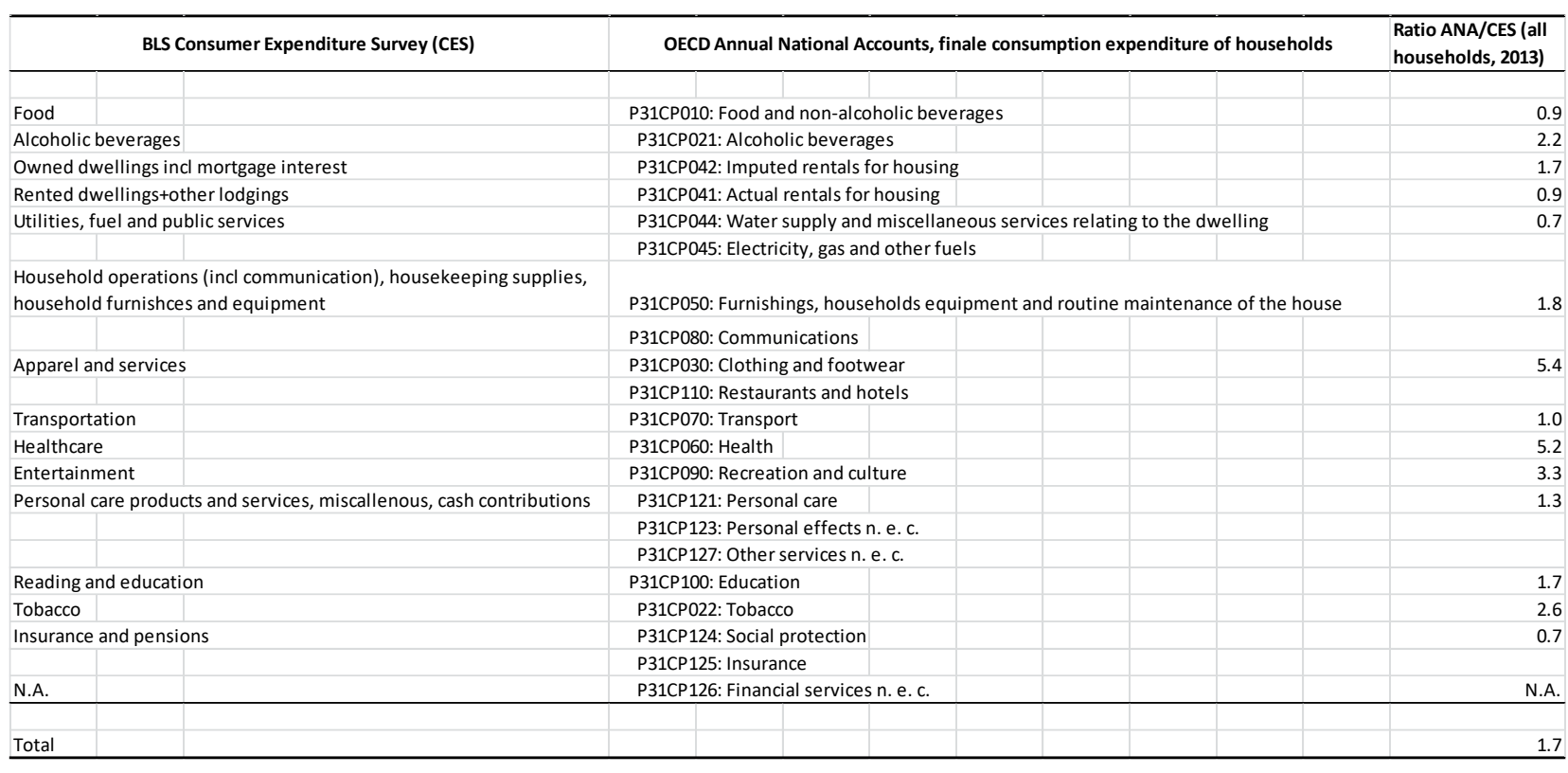

Source: authors' calculations.

\section{From household to social welfare measurement}

\section{Efficiency and equity}

While the measurement of welfare for individual households or groups of households is of interest in itself, it is equally interesting to aggregate across households and so obtain a measure of social welfare that can be followed over time or compared across countries. There is a large body of literature on social welfare measurement and the conditions under which it is possible to carry out inter-household comparisons to form aggregates of welfare measures. Coverage of the topic is far beyond the scope of the present paper and the reader is referred to Slesnick (1998, 2001), Dutta (2002); Chakravarty (2009); Fleurbaey (2009), Cowell (2011) for extensive literature surveys. 
We limit our considerations to issues that are important in the implementation of social welfare functions. A key ingredient to construct measures of social welfare is the measures of individual welfare, based on real consumption $V_{k}\left(W_{k}, A_{k}, p\right)=\frac{p \cdot x_{k}}{m_{0}\left(A_{k}\right) G(p)}$ as presented above. Consider the following average measure $\mathrm{V}$ obtained by dividing aggregate expenditure by the total number of household equivalent members and by applying a consumption price index:

$$
\mathrm{V}=\frac{\sum_{\mathrm{k}=1}^{\mathrm{K}} \mathrm{p} \cdot \mathrm{x}_{\mathrm{k}}}{\mathrm{G}(\mathrm{p}) \sum_{\mathrm{k}=1}^{\mathrm{K}} \mathrm{m}_{0}\left(\mathrm{~A}_{\mathrm{k}}\right)}=\sum_{\mathrm{k}=1}^{\mathrm{K}} \frac{\mathrm{m}_{0}\left(\mathrm{~A}_{\mathrm{k}}\right)}{\sum_{\mathrm{k}=1}^{\mathrm{K}} \mathrm{m}_{0}\left(\mathrm{~A}_{\mathrm{k}}\right)} \frac{\mathrm{p} \cdot \mathrm{x}_{\mathrm{k}}}{\mathrm{G}(\mathrm{p}) \mathrm{m}_{0}\left(\mathrm{~A}_{\mathrm{k}}\right)}=\sum_{\mathrm{k}=1}^{\mathrm{K}} \mathrm{s}_{\mathrm{k}} \mathrm{V}_{\mathrm{k}},
$$

where:

$$
\mathrm{s}_{\mathrm{k}} \equiv \frac{\mathrm{m}_{0}\left(\mathrm{~A}_{\mathrm{k}}\right)}{\sum_{\mathrm{k}=1}^{\mathrm{K}} \mathrm{m}_{0}\left(\mathrm{~A}_{\mathrm{k}}\right)}
$$

We can interpret $\mathrm{V}$ "....as an indicator of efficiency since it is independent of the distribution of welfare across households. That is, a transfer of resources from a rich household to a poor household leaves $V$ unchanged" (Slesnick 2001, p. 27). Efficiency is a distribution-free measure of social welfare, attained at current prices $\mathrm{p}$ for a given aggregate expenditure and population of household equivalent members. This measure is directly available from the national accounts, after adjusting real expenditure for the total number of household equivalent persons.

Efficiency $\mathrm{V}$ is instrumental in de-composing a measure of social welfare that does take account of distributional considerations into efficiency and equity components. To this end, define a social welfare function as:

$$
\mathrm{W}=\mathrm{W}\left(\mathrm{W}_{1}, \mathrm{~W}_{2}, \ldots \mathrm{W}_{\mathrm{K}}\right)
$$


where $\mathrm{W}_{\mathrm{k}}=\mathrm{W}_{\mathrm{k}}\left(\mathrm{V}_{\mathrm{k}}\right)(\mathrm{k}=1, \ldots \mathrm{K})$ is individual well-being. Some key properties of social welfare functions along with two alternative specifications are given in the Annex. Here it suffices to recall that individual welfare has been measured as a function of real consumption expenditure. Similarly, we can define a welfare measure at the level of the total economy, call it $\mathrm{V}^{*}(\mathrm{~W}) 9$ :

$$
\mathrm{W}\left(\mathrm{V}^{*}, \ldots \mathrm{V}^{*}\right)=\mathrm{W}\left(\mathrm{W}_{1}\left(\mathrm{~V}_{1}\right), \mathrm{W}_{2}\left(\mathrm{~V}_{2}\right), \ldots \mathrm{W}_{\mathrm{K}}\left(\mathrm{V}_{\mathrm{K}}\right)\right)
$$

where $\mathrm{V}^{*}=\mathrm{V}^{*}(\mathrm{~W})$ is implicitly defined as the income (or consumption) that, if received by every individual, yields the same social welfare as the actual distribution 10 . We also refer to this measure of social welfare as the standard of living.

Given V*(W), and V, we can apply Jorgenson's (1990) de-composition of V*(W) into equity and efficiency components:

$$
\mathrm{V}^{*}(\mathrm{~W})=\frac{\mathrm{V}^{*}(\mathrm{~W})}{\mathrm{V}} \mathrm{V}
$$

The efficiency component $\mathrm{V}$ was defined above. The other component of $(5), \mathrm{V}^{*}(\mathrm{~W}) / \mathrm{V}$, compares actual social welfare $\mathrm{V} *(\mathrm{~W})$ with potential maximum 11 social welfare $\mathrm{V}$ and thus captures the relative loss in social welfare attributable to an inequitable distribution. This is the 'equity' component of Jorgenson's decomposition. Its derivation requires information about the distribution of consumption per household equivalent member among individuals (or groups of

\footnotetext{
9 Kolm (1969) used the label equal equivalent, Atkinson (1970) equally distributed equivalent income.

10 This is a simplified version of Jorgenson and Slesnick's $(1984,2014)$ social expenditure function.

11 Note that the efficiency measure $V$ can also be interpreted as the level of equally distributed consumption that would give rise to maximum social welfare: one property often assumed for the welfare function $W$ is that it reflects the Dalton (1920) principle which states that a transfer from someone with higher consumption to someone with less is welfare-increasing, as long as the transfer does not lead to a change in ranks between individuals concerns and as long as the transfer is non-leaky (nothing gets lost in the course of redistribution). If $W$ is reflective of the Dalton principle (along with several other properties), $W$ reaches its maximum under equal distribution of income. See Diewert (1985, Theorem 2) for a formal statement.
} 
households) along with a specification of the social welfare function $\mathrm{W}\left(\mathrm{W}_{1}, \ldots \mathrm{W}_{\mathrm{K}}\right)$. A key characteristic of the welfare measure is its dependence on a particular price level - this arises because $\mathrm{V}_{\mathrm{k}}=\mathrm{V}_{\mathrm{k}}\left(\mathrm{W}_{\mathrm{k}}, \mathrm{A}_{\mathrm{k}}, \mathrm{p}\right)$, the determinants of $\mathrm{W}\left(\mathrm{W}_{1}\left(\mathrm{~V}_{1}\right) \ldots \mathrm{W}_{\mathrm{k}}\left(\mathrm{V}_{\mathrm{K}}\right)\right)$, are themselves dependent on a particular price level p.

A simple transformation of (5) helps introducing a family of indexes of relative inequality in the tradition of Kolm (1969) and Atkinson (1970):

$$
\mathrm{V}^{*}(\mathrm{~W})=(1-\mathrm{I}(\mathrm{W}, \mathrm{V})) \mathrm{V} \text { with } \mathrm{I}(\mathrm{W}, \mathrm{V}) \equiv 1-\frac{\mathrm{V}^{*}(\mathrm{~W})}{\mathrm{V}}
$$

A social welfare function and the associated measure of inequality explicitly introduce ethical judgements about equity into measurement. The precise way this is done depends on the functional form of the social welfare function. In the two specifications discussed in the annex this happens by way of a parameter (Degree of Aversion to Inequality), to be set by analysts or policymakers, that allows the statistician to produce measures of social welfare for a given judgement on distribution. Although the inequality parameter can take many different values, a pragmatic approach is to show two particular cases that limit the value of the inequality component from below and from above. Under the utilitarian case (in the sense of Jorgenson-Slesnick), the equity component in (5) and the inequality measure in (6) take the smallest admissible value within the specifications of the welfare function. Under the egalitarian case, the equity component and the inequality measure take the largest admissible value within Jorgenson-Slesnick's specifications of the welfare function.

It is shown in the Annex that the utilitarian case under the Jorgenson-Slesnick specification amounts to aggregating real consumption of different groups of households by means of a geometric average. This is equivalent to the Cobb-Douglas case under the Atkinson specification 
and is particularly simple to implement. It implies measuring inequality $\mathrm{I}(\mathrm{W}, \mathrm{V})$ as one minus the ratio of a geometric over an arithmetic average of equivalent consumption of different groups of households. We are now ready to move towards some illustrative empirical results for both specifications.

\section{Results}

A first set of results is presented in Table 4. It starts with the elements of the efficiency component of the social welfare measure. These are: (i) private household consumption expenditure as available from the US National Income and Product Accounts expressed in constant 2005 dollars; (ii) the economy-wide number of household equivalent individuals computed on the basis of three different equivalent scales; and (iii) the ratio of (i) over (ii) which yields $V$, our measure of efficiency. The notable point here is the large differences in level and evolution of the number of household equivalent members between the multi-dimensional Jorgenson-Slesnick measure and the single-dimensional Barten scale and OECD scale. As the multi-dimensional adjustment has a stronger theoretical foundation than the single-dimensional adjustment for household size only, we conclude that important information gets lost by moving to a size-only equivalence scale. Obviously, the advantage of the single-dimensional equivalence scale lies in its simplicity. But structural shifts in the composition of households other than their size will go unnoticed and may introduce a bias of unknown size. Indeed, the number of household equivalent members under the Jorgenson-Slesnick scale significantly exceeds the population size of the United States. While a declining household size (as observed in the country) reduces the number of household equivalent members, an upward shift in the age structure or a shifting ethnical composition towards non-white persons will increase the number of household equivalent members. We also note that the differences in trend between the two single- 
dimensional measures are small so the choice between single-dimensional scales - the Barten scale and the OECD scale in the case at hand - will have little effect on the evolution of the overall measure of efficiency.

Table 3. Personal consumption expenditure

\begin{tabular}{|c|c|c|c|c|c|c|c|c|}
\hline & $\begin{array}{c}\text { Private } \\
\text { Consumption } \\
\text { expenditure billions } \\
\text { of current } \$\end{array}$ & $\begin{array}{c}\text { Private } \\
\text { Consumption } \\
\text { expenditure } \\
\text { deflator }(2005=1)\end{array}$ & $\begin{array}{c}\text { Private } \\
\text { Consumption } \\
\text { expenditure } \\
\text { billions of } 2005 \$\end{array}$ & $\begin{array}{c}\text { Household } \\
\text { equivalent } \\
\text { members, millions } \\
\text { (single-dimension } \\
\text { Barten scale) }\end{array}$ & $\begin{array}{l}\text { Household } \\
\text { equivalent } \\
\text { members, } \\
\text { millions (OECD } \\
\text { scale) }\end{array}$ & $\begin{array}{c}\text { Household } \\
\text { equivalent } \\
\text { members, millions } \\
\text { (multi-dimensional } \\
\text { Barten scale - } \\
\text { Jorgenson-Slesnick } \\
\text { scale 2014) }\end{array}$ & $\begin{array}{c}\text { Private } \\
\text { Consumption } \\
\text { expenditure per } \\
\text { household } \\
\text { equivalent member } \\
\text { (OECD scale), } 2005 \\
\$\end{array}$ & $\begin{array}{l}\text { Private } \\
\text { Consumption } \\
\text { expenditure per } \\
\text { houshold } \\
\text { equivalent member } \\
\text { (multi-dimensional } \\
\text { Barten scale - } \\
\text { Jorgenson-Slesnick } \\
\text { scale 2014), 2005\$ }\end{array}$ \\
\hline 2005 & 8589 & 1.000 & 8589 & 238.7 & 185.6 & 472.0 & 46286 & 18260 \\
\hline 2006 & 9066 & 1.027 & 8826 & 241.7 & 187.9 & 476.6 & 46971 & 18670 \\
\hline 2007 & 9512 & 1.053 & 9035 & 244.4 & 190.0 & 481.4 & 47549 & 18970 \\
\hline 2008 & 9750 & 1.085 & 8983 & 245.7 & 191.0 & 489.5 & 47045 & 18770 \\
\hline 2009 & 9588 & 1.086 & 8829 & 245.8 & 191.1 & 496.1 & 46205 & 18260 \\
\hline 2010 & 9954 & 1.105 & 9011 & 246.3 & 191.5 & 501.6 & 47056 & 18360 \\
\hline 2011 & 10448 & 1.132 & 9226 & 248.7 & 193.4 & n.a. & 47716 & n.a. \\
\hline 2012 & 10827 & 1.154 & 9381 & 253.1 & 196.7 & n.a. & 47689 & n.a. \\
\hline 2013 & 11219 & 1.168 & 9608 & 255.6 & 198.7 & n.a. & 48353 & n.a. \\
\hline $2005-2013$ & $3.40 \%$ & $1.96 \%$ & $1.41 \%$ & $0.86 \%$ & $0.86 \%$ & & $0.55 \%$ & \\
\hline $2005-2010$ & $3.00 \%$ & $2.01 \%$ & $0.96 \%$ & $0.63 \%$ & $0.63 \%$ & $1.22 \%$ & $0.33 \%$ & $0.11 \%$ \\
\hline
\end{tabular}

Source: OECD annual national accounts data base and authors' calculations. Note that the private consumption data underlying Jorgenson and Slesnick (2014 - last columns) are of a different vintage from the consumption data in the OECD national accounts. Data in the last column is consistent with the series shown Table 5.

The next step consists of computing the welfare measure $\mathrm{V}(\mathrm{W})$ along the specifications in the Annex and de-compose social welfare into its efficiency and equity components. We illustrate this step with results for (i) the utilitarian case where social welfare reduces to a geometric average of individual real consumption; (ii) the egalitarian case where maximum weight (within the other constraints of the welfare function - see annex) is given to inequality. The results presented are those by Jorgenson-Slesnick (2014) as they cover a time span of several decades, appropriate to gauge trends in the overall evolution of social welfare and its break-down into an efficiency and an inequality component. 
Table 5. Contributions to growth of the standard of living, United States

\begin{tabular}{|c|c|c|c|c|c|c|}
\hline & \multicolumn{6}{|c|}{ Average annual growth rates } \\
\hline & $1948-2010$ & $1948-1973$ & 1973-1995 & $1995-2000$ & $2000-2005$ & $2005-2010$ \\
\hline & \multicolumn{6}{|c|}{ Egalitarian* } \\
\hline Standard of living (social welfare) & 2.34 & 3.45 & 1.87 & 1.96 & 1.82 & -0.27 \\
\hline $\begin{array}{l}\text { Efficiency (Personal } \\
\text { consumption expenditure per } \\
\text { household equivalent } \\
\text { member, } 2005 \$ \text { ) }\end{array}$ & 2.16 & 2.67 & 1.97 & 2.65 & 2.03 & 0.11 \\
\hline Equity & 0.17 & 0.78 & -0.11 & -0.68 & -0.21 & -0.37 \\
\hline & & & & & & \\
\hline & \multicolumn{6}{|c|}{ Utilitarian* } \\
\hline Standard of living (social welfare) & 2.24 & 3.09 & 1.90 & 2.20 & 1.93 & -0.12 \\
\hline $\begin{array}{l}\text { Efficiency (Personal } \\
\text { consumption expenditure per } \\
\text { household equivalent } \\
\text { member, } 2005 \$ \text { ) }\end{array}$ & 2.16 & 2.67 & 1.97 & 2.65 & 2.03 & 0.11 \\
\hline Equity & 0.08 & 0.42 & -0.07 & -0.44 & -0.10 & -0.23 \\
\hline ee Annex for definitions & & & & & & \\
\hline
\end{tabular}

Source: Jorgenson and Slesnick (2014), Table 3.7.

Over the period considered, efficiency growth was strongest between 1948-1973. This postwar period until the early seventies was also the time when equity rose, however measured. Subsequent slowing of the growth rate of average consumption per household equivalent member, combined with a rise in inequality led to a slower growth in social welfare. Living standards actually declined during the period 2005-10 where positive but weak efficiency growth is outweighed by a rise in relative inequality. The rise in inequality and the drop in the standard of living is perceptible under both the egalitarian and the utilitarian approach 12.

12 By way of comparison, we carried out an alternative computation following Sen's (1973) social welfare measure by adjusting the average consumer expenditure per household equivalent member by the Gini coefficient. Over a comparable period (1979-2010), the two measures yield similar orders of magnitude for social welfare (around 1.6\% per year for our own result and $1.4 \%$ for Sen-type measure). The correlation coefficient of yearly rates of change is around 0.7 . However, differences can be important for shorter periods. For example, while the Jorgenson-Slesnick (2014) measure shows a decline in the overall standard of living in the years following 2005 this is not picked up by the simple Gini-adjusted metric. 


\section{Conclusions}

Real household consumption per capita is a measure routinely employed as an indicator of economic well-being. We argue that head-count measures of the population should be replaced by measures of equivalent household members, price indices should be group-specific, and equity considerations should be introduced and made explicit.

Jorgenson and Slesnick $(1983,1987,2014)$ have developed the theory and methodology for full empirical implementation of these features. This may, however, not always be feasible, and the question is whether empirically more tractable measures of individual and social welfare can be derived that preserve some key features of well-founded welfare measures. Statistical offices could use these simplified approaches to gain experience in developing and analysing distributional information within the setting of the national accounts. They could then experiment with less restrictive assumptions about measures of individual and social welfare in order to respond more fully to user interest in distributional issues.

Four key steps are required to implement social welfare measures. The first is a scaling of household consumption expenditure by the number of household equivalent members. We find that the choice of the equivalence scale matters, in particular when passing from the established one-dimensional, size-based scale to a multi-dimensional scale that incorporates demographic variables other than household size.

The second step is conversion of current price expenditure into constant price measures. We use data from the U.S. Consumer Expenditure Survey and the OECD national accounts to construct simplified national accounts compatible measures of individual welfare. In particular we 
test the effects of using group-specific deflators as opposed to aggregate consumption deflators from the national accounts. We conclude that for the case at hand, effects are small.

The third step is aligning survey-based consumption categories to the consumption expenditure categories in the national accounts. As the work of the EG DNA shows, the effect on the resulting welfare measures for different household groups can be significant and underlines the need for a careful adjustment of survey sources.

The fourth step is introducing a social welfare measure to aggregate across individual welfare measures. Aggregate welfare, it is shown, can be presented as the sum of an efficiency effect (directly available from the national accounts after application of equivalence scales) and an equity effect that represents the welfare impact of inequality. The key issue here is to make ethical judgements explicit as the size of the equity effect will be directly related to society's aversion to inequality which is a normative choice. We discuss two specifications for a social welfare function and identify one particularly simple case where the two measures coincide.

We conclude by recommending that distributional information should be incorporated into national accounts. This process could begin with a household satellite system for measuring consumption expenditure and income broken down by relevant demographic and economic attributes such as household size, region, age of household members and consumption and income levels, very much in the spirit of Social Accounting Matrices that have long been present in the national accounts literature. Such information provides the necessary ingredients to compile group-specific cost of living indices, to express and to compare individual economic well-being per household equivalent member and to construct a social welfare measure with explicit normative choices. 


\section{ANNEX FURTHER DISCUSSION OF SOCIAL WELFARE FUNCTIONS}

This annex provides some additional detail on social welfare functions to the extent that such detail is useful in the context of implementing social welfare measurement in the national accounts. The literature on social welfare functions is large and a discussion of the theory of social welfare functions is well beyond the scope of the present paper. The interested reader is referred to Slesnick (1998), Dutta (2002), Pattanaik (2008) and Fleurbaey (2009) for surveys of the literature.

\section{Properties of social welfare functions}

The concept of social welfare functions was first introduced by Bergson (1938) and further developed by Samuelson (1947). In essence, a social welfare function assigns exactly one real value to each feasible social state. For the purpose at hand, each social state depends only on individual welfare, so that the social welfare function (3) assigns a single value to each ordering of individual welfare. It will be assumed that the following properties apply: (i) independence of irrelevant alternatives, i.e., the comparison of any two distributions of household utility is independent of a third distribution of household utility; (ii) symmetry, i.e., any permutation of the order by which individuals appear in the welfare function has no impact on the aggregate welfare measure; (iii) linear homogeneity, i.e., a proportional change of every individual's welfare raises social welfare by the same proportion; (iv) the social welfare function is increasing in its elements: a rise in any individual's welfare should always translate into a rise in social welfare, everything else constant. This is a formulation of the Pareto principle and not entirely innocuous. It implies, for instance that even in a situation where the distribution of household welfare is very skewed, an additional dollar of consumption available to rich households entails a rise in social welfare; (v) cardinal interpersonal comparability. This requires that social welfare orderings are invariant with respect to positive affine 
transformations that are the same for all individuals13. A formal discussion of these properties can in particular be found in Roberts (1980), Jorgenson and Slesnick (1983) and Diewert (1985).

Roberts (1980) demonstrates that cardinal inter-personal comparability of utility is in particular compatible with two functional forms presented here, the Jorgenson-Slesnick social welfare function, and the Atkinson social welfare function.

\section{Jorgenson-Slesnick welfare function}

Jorgenson and Slesnick's $(1983,1984)$ define individual welfare as the logarithmic transformation of real consumption expenditure per household equivalent member, $\mathrm{W}_{\mathrm{k}}=\ln \left(\mathrm{V}_{\mathrm{k}}\right)$ and then define a class of social welfare functions that combines the average level of household welfare with deviations of (logarithmic) individual real expenditure levels from average:

$$
\begin{aligned}
\mathrm{W}_{\mathrm{JS}} & \left(\mathrm{W}_{1}, \mathrm{~W}_{2}, \ldots \mathrm{W}_{\mathrm{K}}\right) \\
& =\mathrm{W}_{\mathrm{JS}}\left(\ln \mathrm{V}_{1}, \ln \mathrm{V}_{2}, \ldots \ln \mathrm{V}_{\mathrm{K}}\right) \\
& =\ln \overline{\mathrm{V}_{\mathrm{JS}}}-\gamma\left[\sum_{\mathrm{k}=1}^{\mathrm{K}} \mathrm{s}_{\mathrm{k}}\left|\ln \mathrm{V}_{\mathrm{k}}-\ln \overline{\mathrm{V}_{\mathrm{JS}}}\right|^{-\rho}\right]^{-1 / \rho}
\end{aligned}
$$

In (7), $\ln \overline{V_{J S}}=\frac{1}{K} \sum_{1}^{K} s_{k} \ln V_{k}$ is a weighted average of log real consumption per household equivalent member. Weights $s_{k} \equiv \frac{m_{0}\left(A_{k}\right)}{\sum_{k} m_{0}\left(A_{k}\right)}$ represent the share of each household or group of households $(\mathrm{k}=1, \ldots \mathrm{K})$ in the total number of household equivalent members. $\rho$ is a parameter that reflects aversion to inequality. We first note that $-\infty \leq \rho \leq-1$. Setting the upper bound of $\rho$ at

13 A special case of an affine transformation is a linear transformation where the origin is kept at zero. Roberts (1980) has demonstrated that the more general case of an affine transformation is associated with a somewhat weaker assumption about cardinal comparability ('full cardinal comparability' in his dictum) than the linear transformation ('cardinal ratio comparability'). Jorgenson-Slesnick's (1983) welfare function is an example for full cardinal comparability, Atkinson's (1970) welfare function is an example for cardinal ratio comparability (Roberts 1980). By contrast Arrow (1963) assumes ordinal non-comparability of household welfare measures and derives the famous "Arrow impossibility theorem." See also Fleurbaey and Blanchard (2013) for a discussion of Arrow's theorem and welfare measurement. 
minus one implies that $\mathrm{W}_{\mathrm{JS}}\left(\ln _{1}, \ln _{2}, \ldots \ln \mathrm{V}_{\mathrm{K}}\right)$ is concave in its arguments (Diewert 1985, p.79). Concavity, in turn implies that Dalton's transfer principle is observed (see footnote 11). The parameter $\gamma$ has to be non-negative so that social welfare declines with increasing inequality.

The social expenditure VIS*(WJS) is readily established as $\mathrm{VIS}_{\mathrm{JS}}(\mathrm{WJS})=\exp \left(\mathrm{WJS}_{\mathrm{JS}}\right)$ and can be computed by inserting the values $\ln \left(\mathrm{V}_{\mathrm{k}}\right)$ of individual welfare into (A.1). We start by examining the special case of VJS* (WJS) with two households: $\mathrm{K}=2$ :

$$
\begin{aligned}
& \left.\ln V_{\mathrm{JS}}^{*}\right|_{\mathrm{K}=2}= \\
& =s_{1} \operatorname{lnV}_{1}+s_{2} \ln V_{2}-\gamma\left[s_{1}\left|\ln V_{1}-\frac{1}{2}\left(\operatorname{lnV}_{1}+\ln V_{2}\right)\right|^{-\rho}+s_{2}\left|\ln V_{2}-\frac{1}{2}\left(\operatorname{lnV}_{1}+\ln V_{2}\right)\right|^{-\rho}\right]^{-\frac{1}{\rho}} \\
& =\left(\mathrm{s}_{1}-\frac{\gamma}{2}\right) \ln \mathrm{V}_{1}+\left(\mathrm{s}_{2}+\frac{\gamma}{2}\right) \ln \mathrm{V}_{2} \quad \text { for } 0 \leq \mathrm{V}_{1} \leq \mathrm{V}_{2} .
\end{aligned}
$$

From (A.2) it is apparent that for the case of $K=2$, the social welfare function and the associated inequality measures become independent of $\rho 14$. This is not the case for $K \geq 3$. We shall thus limit discussion to $\mathrm{K} \geq 3$ in what follows which is a weak constraint for practical purposes where distributional data will typically be available in quintiles $(K=5)$, deciles $(K=10)$ or with even more detail especially if household-level micro data is used.

(A.2) is also useful with a view to determining the value at which $\gamma$ should be set. One of the properties of the social welfare function is that it should be increasing in its elements. It can be verified that for the case of $\mathrm{K}=2, \ln \mathrm{VJS}_{\mathrm{JS}} *$ is increasing for $-2 \mathrm{~s} 1<\gamma<2 \mathrm{~s} 2$. However, $\gamma$ has to be nonnegative if higher inequality (second term on the right hand side of A.1) should reduce social welfare. Hence, we limit $\gamma$ to $0 \leq \gamma<2 \mathrm{~s} 2$. As it is a-priori unclear whether s1 is smaller or larger than $\mathrm{s} 2$, the bounds for $\gamma$ become $0 \leq \gamma<\min (2 \mathrm{sk})$. If maximum weight should be given to inequality in

\footnotetext{
14 We thank Erwin Diewert for this and many other helpful observations.
} 
(A.2), while preserving the characteristic of a welfare function that is increasing, $\gamma$ should be set at $\gamma=\min (2 \mathrm{sk})$.

We next turn to the parameter $\rho$ that captures aversion to inequality. Two cases are of particular interest here.

$\rho \rightarrow-\infty$ : in this case, the second term on the right hand side of (A.1) disappears and the social welfare measure VIS*(WJS)=exp(WıS) reduces to a geometric average over individual welfare. Jorgenson and Slesnick (1984) labelled this the utilitarian case as no explicit consideration is given to inequality. Note an important point, however. Although Jorgenson and Slesnick's utilitarian case corresponds to an arithmetic average over household's utilities $\mathrm{W}_{\mathrm{k}}$, the latter are measured as natural logarithms of real household expenditure (implying decreasing marginal utility in consumption). It follows that, in the utilitarian case VJS $\left.\right|_{\rho \rightarrow-\infty}=\exp \left(\left.\mathrm{WJS}_{\mathrm{J}}^{*}\right|_{\rho \rightarrow-\infty}\right)$ $=\exp \left(\sum \mathrm{sk} \ln \mathrm{V}_{\mathrm{k}}\right)=\prod \mathrm{V}_{\mathrm{ksk}}$ is a geometric average over real household expenditure.It is straight forward to see that under the utilitarian case, the social welfare measure $\ln \left(V_{J S}^{*}\right)_{\mid \rho \rightarrow-\infty}=\ln \overline{V_{J S}}=$ $\sum_{\mathrm{k}=1}^{\mathrm{K}} \mathrm{s}_{\mathrm{k}} \ln \mathrm{V}_{\mathrm{k}}$ is increasing in $\mathrm{V}_{\mathrm{k}}$.

$\rho=-1$ : in this egalitarian case, maximum weight is given to the part of (7) that reflects inequality. The welfare measure now becomes $\ln \left(V_{\mathrm{JS}}^{*}\right)_{\mid \rho=-1}=\mathrm{W}_{\mathrm{JS}}\left(\ln V_{1}, \ln V_{2}, \ldots \ln \mathrm{V}_{\mathrm{K}}\right)_{\mid \rho=-1}=$ $\ln \overline{\mathrm{V}_{\mathrm{JS}}}-\gamma \sum_{\mathrm{k}=1}^{\mathrm{K}} \mathrm{s}_{\mathrm{k}}\left|\ln \mathrm{V}_{\mathrm{k}}-\ln \overline{\mathrm{V}_{\mathrm{JS}}}\right|$. The inequality term presents itself as a weighted sum of absolute deviations of log real household expenditure from their mean. We establish the size of $\gamma \geq 0$ as the largest value compatible with the Pareto criterion, i.e., an increase of individual welfare should never lead to a decrease in societal welfare, everything else constant. Consider the first derivative of $\ln \left(\mathrm{V}_{\mathrm{JS}} *\right)$ with respect to an arbitrary $\mathrm{V}_{\mathrm{h}}(\mathrm{h}=1,2, \ldots \mathrm{K})$ : 


$$
\begin{aligned}
& \frac{\partial \ln V_{\mathrm{JS}}^{*}}{\partial \ln V_{\mathrm{h}} \rho \rho=-1}=s_{\mathrm{h}}-\gamma \sum_{\mathrm{k}=1, \mathrm{k} \neq \mathrm{h}}^{\mathrm{K}} \mathrm{s}_{\mathrm{k}} \frac{\ln \mathrm{V}_{\mathrm{k}}-\ln \overline{\mathrm{V}_{\mathrm{JS}}}}{\left|\ln \mathrm{V}_{\mathrm{k}}-\ln \overline{\mathrm{V}_{\mathrm{JS}}}\right|}\left(-s_{\mathrm{h}}\right)+\left(1-\mathrm{s}_{\mathrm{h}}\right) \frac{\ln \mathrm{V}_{\mathrm{h}}-\ln \overline{\mathrm{V}_{\mathrm{JS}}}}{\left|\ln \mathrm{V}_{\mathrm{h}}-\ln \overline{\mathrm{V}_{\mathrm{JS}}}\right|} \\
& =s_{h}-\gamma s_{h}\left\{-\sum_{k=1, k \neq h}^{K} s_{k} \frac{\ln V_{k}-\ln \overline{V_{J S}}}{\left|\ln V_{k}-\ln \overline{V_{J S}}\right|}+\left(1-s_{h}\right) \frac{\ln V_{h}-\ln \overline{V_{J S}}}{\left|\ln V_{h}-\ln \overline{V_{J S}}\right|}\right\}
\end{aligned}
$$

Compliance with the Pareto criterion requires that the elasticity of social welfare with respect to a change in individual welfare is non-negative. We set $\gamma$ at the largest possible value consistent with a non-negative first derivative. Inspection of the right hand side of (A.3) shows that the term in brackets reaches its maximum positive value when $\ln V_{h} \geq \ln \bar{V} \cap s_{h}=\min \left(s_{k}\right)(k=1, \ldots K) \cap$ $\ln V_{\mathrm{k} \neq \mathrm{h}} \geq \ln \bar{V}$. Under this constellation, the term in bracket becomes $\left\{\sum_{\mathrm{k}=1}^{\mathrm{K}} \mathrm{s}_{\mathrm{k}}+(1-\right.$ $\left.\left.\min \left(s_{\mathrm{k}}\right)\right)\right\}=\left\{1-\min \left(s_{k}\right)+1-\min \left(s_{k}\right)\right\}=2\left(1-\min \left(s_{k}\right)\right)$. Consequently, $\quad$ we $\quad$ set $\quad \gamma=$ $\left(2\left(1-\min \left(s_{k}\right)\right)^{-1}\right.$. This is a special case for $\rho=-1$ of the more general formula provided by Jorgenson(1990): $\gamma=\left\{\left[1-\min \left(s_{k}\right)\right]\left[1+\left(\frac{\left(1-\min \left(s_{k}\right)\right)}{\min \left(s_{k}\right)}\right)^{-(\rho+1)}\right]\right\}^{1 / \rho}$.

One notes that the elasticity of social welfare with respect to consumption of a particular household as shown in (A.3) is constant at $\rho=-1$, which follows from further differentiating (A.3) with respect to individual welfare: $\left.\frac{\partial^{2} \ln V_{J S}^{*}}{\partial{\ln V_{h}}^{2}}\right|_{\rho=-1}=0$. It may be argued that this is an undesirable result as it implies that a percentage change in consumption of a household at the top of the consumption pyramid induces the same percentage change in social welfare as an extra percent of consumption for a household at the bottom of the consumption ladder. This drawback has to be judged against the advantage of using a rather simple set-up. Also, a constant elasticity implies that the absolute change in social welfare due to an extra dollar of real consumption is inversely 
proportional to the initial level of consumption and thus higher for a low-consumption household than for a high-consumption household.

\section{Atkinson welfare function}

Our second suggestion for a specification of the social welfare function is Atkinson's (1970) generalised mean over individual economic well-being 15 . Here, individual well-being is directly measured as real household expenditure per household equivalent member: $\mathrm{W}_{\mathrm{k}}=\mathrm{V}_{\mathrm{k}}(\mathrm{k}=1, \ldots \mathrm{K})$. For the social welfare function, we introduce a small addition to Atkinson's formulation by allowing for different weights sk for each element $\mathrm{V}_{\mathrm{k}}$ :

$$
\begin{array}{ll}
W_{A}\left(W_{1}, W_{2}, \ldots W_{K}\right)=W_{A}\left(V_{1}, V_{2}, . V_{K}\right)=\left[\sum_{k=1}^{K} S_{k} V_{k}^{-\tau}\right]^{-1 / \tau} & \text { for } \tau \neq 0 \\
W_{A}\left(W_{1}, W_{2}, \ldots W_{K}\right)=W_{A}\left(V_{1}, V_{2}, \ldots V_{K}\right)=\prod_{k=1}^{K} V_{k}^{s_{k}} & \text { for } \tau=0
\end{array}
$$

The social expenditure $\mathrm{VA}^{*}\left(\mathrm{~W}_{\mathrm{A}}\right)$ is easily established as $\mathrm{V}_{\mathrm{A}}^{*}\left(\mathrm{~W}_{\mathrm{A}}\right)=\mathrm{W}_{\mathrm{A}}$ and can be computed by inserting the values $V_{k}$ of individual welfare into (A.4). To determine the range of $\tau$, we start by invoking a result on the properties of generalised means. Hardy, Littlewood and Polya (1934, p.30 - quoted after Diewert 1993) demonstrate that $\mathrm{W}_{\mathrm{A}}\left(\mathrm{V}_{1}, \ldots \mathrm{V}_{\mathrm{K}}\right)$ is a concave function over the positive orthant $\left(\mathrm{V}_{\mathrm{k}}>>0(\mathrm{k}=1, \ldots \mathrm{K})\right)$ if and only if $\tau \geq-1$. As concavity is one of the required properties of the social welfare function, we limit the curvature parameter to $-1 \leq \tau \leq \infty$. Next, differentiate $\ln \mathrm{W}_{\mathrm{A}}$ with respect to $\ln \mathrm{V}_{\mathrm{h}}(\mathrm{h}=1, \ldots \mathrm{K})$ :

$$
\frac{\partial \ln V_{\mathrm{A}}^{*}}{\partial \ln V_{\mathrm{h}}}=\frac{\partial \ln \mathrm{W}_{\mathrm{A}}}{\partial \ln V_{\mathrm{h}}}=\frac{\partial \mathrm{W}_{\mathrm{A}}}{\partial \mathrm{V}_{\mathrm{h}}} \frac{\mathrm{V}_{\mathrm{h}}}{\mathrm{W}_{\mathrm{A}}}=\frac{\mathrm{s}_{\mathrm{h}} \mathrm{V}_{\mathrm{h}}^{-\tau}}{\sum_{\mathrm{k}=1}^{\mathrm{K}} \mathrm{s}_{\mathrm{k}} \mathrm{V}_{\mathrm{k}}^{-\tau}}>0 \quad \text { for }-1 \leq \tau \leq \infty, \tau \neq 0
$$

\footnotetext{
15 For a discussion of Atkinson's measure see Diewert (1985), Deaton and Muelbauer (1980) and Blackorby and Donaldson (1978).
} 


$$
\frac{\partial \ln V_{\mathrm{A}}^{*}}{\partial \ln V_{\mathrm{h}}}=\frac{\partial \ln \mathrm{W}_{\mathrm{A}}}{\partial \ln V_{\mathrm{h}}}=\frac{\partial \mathrm{W}_{\mathrm{A}}}{\partial \mathrm{V}_{\mathrm{h}}} \frac{\mathrm{V}_{\mathrm{h}}}{\mathrm{W}_{\mathrm{A}}}=s_{h}>0 \quad \text { for } \tau=0
$$

WA is thus increasing in individual welfare. Further inspection of the elasticity in (A.5) shows that the elasticity itself is increasing for $0>\tau \geq-1$, constant for $\tau=0$ and decreasing for $\infty>\tau>0$ :

$$
\frac{\partial \ln V_{\mathrm{A}}^{*}}{\partial \ln V_{\mathrm{h}}{ }^{2}}=\frac{\partial}{\partial \ln V_{\mathrm{h}}}\left[\frac{\mathrm{s}_{\mathrm{h}} \mathrm{V}_{\mathrm{h}}^{-\tau}}{\sum_{\mathrm{k}=1}^{\mathrm{K}} \mathrm{s}_{\mathrm{k}} \mathrm{V}_{\mathrm{k}}^{-\tau}}\right]=\frac{\partial}{\partial \mathrm{V}_{\mathrm{h}}}\left[\frac{\mathrm{s}_{\mathrm{h}} \mathrm{V}_{\mathrm{h}}^{-\tau}}{\sum_{\mathrm{k}=1}^{\mathrm{K}} \mathrm{s}_{\mathrm{k}} \mathrm{V}_{\mathrm{k}}^{-\tau}}\right] \mathrm{V}_{\mathrm{h}}=-\tau \mathrm{s}_{\mathrm{h}} \frac{\partial \ln \mathrm{V}_{\mathrm{A}}^{*}}{\partial \ln \mathrm{V}_{\mathrm{h}}}\left\{1-\frac{\partial \ln \mathrm{V}_{\mathrm{A}}^{*}}{\partial \ln \mathrm{V}_{\mathrm{h}}}\right\}
$$

An increasing elasticity may be considered undesirable as it implies an increasing relative change in social welfare the further up a household is on the consumption ladder. We therefore limit the range of $\tau$ to the non-negative domain: $\infty>\tau \geq 0$. We include the special case of $\tau=0$ for the same reasons as mentioned above in the context of the Jorgenson-Slesnick specification.

\section{A comparison}

In comparing the Jorgenson-Slesnick and the Atkinson social expenditure measures VJS* and $\mathrm{VA}^{*}$ we first remark that the two measures coincide for the utilitarian case $\left.\mathrm{V}_{\mathrm{JS}}^{*}\right|_{\rho \rightarrow-\infty}=$ $\prod_{\mathrm{k}=1}^{\mathrm{K}} \mathrm{V}_{\mathrm{k}}^{\mathrm{S}_{\mathrm{k}}}=\left.\mathrm{V}_{\mathrm{A}}^{*}\right|_{\tau=0}$. This is indeed a rather simple way of portraying the efficiency-equity tradeoff. Invoking relationships (6) and (2) from the main text, the social welfare de-composition takes the following form:

$$
\mathrm{V}_{\mathrm{JS}}^{*}=\mathrm{V}_{\mathrm{A}}^{*}=\left(\sum_{\mathrm{k}=1}^{\mathrm{K}} \mathrm{s}_{\mathrm{k}} \mathrm{V}_{\mathrm{k}}\right)\left(\frac{\prod_{\mathrm{k}=1}^{\mathrm{K}} \mathrm{V}_{\mathrm{k}}^{\mathrm{s}_{\mathrm{k}}}}{\sum_{\mathrm{k}=1}^{\mathrm{K}} \mathrm{s}_{\mathrm{k}} \mathrm{V}_{\mathrm{k}}}\right)
$$

In (A.7), the simple ratio between a weighted geometric average and a weighted arithmetic average of real household consumption gives rise to the equity component of the social welfare measure. Thus, under the utilitarian set-up for Jorgenson-Slesnick and the Cobb-Douglas formulation for Atkinson, both the social welfare measure and the inequality measure are 
identical. This case has several advantages. First, it is easy to implement. Although there is an implicit choice of $\tau$ and $\rho$, none of these parameters appears explicitly, and neither does $\gamma$. Second, and more importantly, the geometric average is identical to or approximates the median of an (approximately) log-normally distributed variable. Empirically, household consumption and income tend to be well-described by log-normal distributions and in these cases the geometric mean will be a good approximation to the median. The median itself is a variable of considerable analytical and policy interest as it captures well what can be considered a 'representative' household, or the 'middle class'. The main disadvantage of the geometric average is that it does not give much weight to the more extreme parts of the distribution.

As the Atkinson specification is a generalised mean of order $\tau$, it holds that $\lim _{\tau \rightarrow \infty} \mathrm{V}_{\mathrm{A}}^{*}=$ $\min \left(V_{1}, \ldots V_{k}\right)$. Thus, with aversion to inequality set at a very high value, the Atkinson welfare function reduces to the welfare of the poorest household or the poorest group of households. While monitoring the welfare of the poorest households may be of analytical interest in some cases, the resulting measure no more reflects inequality and becomes independent from the level of welfare of other households. This may be considered an undesirable property and we may wish to limit $\tau$ from below so that the formula remains sensitive to changes in inequalities. There appears to be no general theoretical way of determining such a boundary, however. We therefore evaluate a lower limit $\tau_{\min }$ numerically by measuring the value of $\tau$ that gives rise, for a given distribution, to the same welfare measure as the egalitarian version of Jorgenson-Slesnick that limits their welfare measure from below: $\frac{-1}{\tau_{\min }} \ln \left(\sum_{\mathrm{k}=1}^{\mathrm{K}} \mathrm{s}_{\mathrm{k}} \mathrm{V}_{\mathrm{k}}^{-\tau_{\min }}\right)=\left.\mathrm{W}_{\mathrm{JS}}\left(\mathrm{V}_{1}, \ldots \mathrm{V}_{\mathrm{k}}\right)\right|_{\rho=-1}$. 
We generate samples of log-normally distributed random variables with a benchmark mean and standard deviation 16 and solve the above equation for $\tau_{\min }$. For the benchmark values, $\tau_{\min }$ is about 2.5. Next, we test compare numerical results for the inequality measures associated with the two specifications. For the parameter constellation $\{\rho=-1, \tau=2.5, \mu=\ln (39000), \sigma=0.2\}$ we draw 50 random samples of size 10000. For each sample, we form deciles and compute social welfare measures $\mathrm{VA}_{\mathrm{A}^{*}}$, VIS*, and indicators of relative inequality $\mathrm{IA}_{\mathrm{A}}$, IJs. We then compute the average across the 50 samples. Next, we progressively increase the distributional parameter $\sigma$ to examine how the inequality measures IA, IJs behave as distributions become more unequal. It turns out that IA and Iss are highly correlated and exhibit similar movements as $\sigma$ increases although the Atkinson type inequality measure rises somewhat quicker than the Jorgenson-Slesnick specification.

Sensitivity of inequality measures to widening distribution

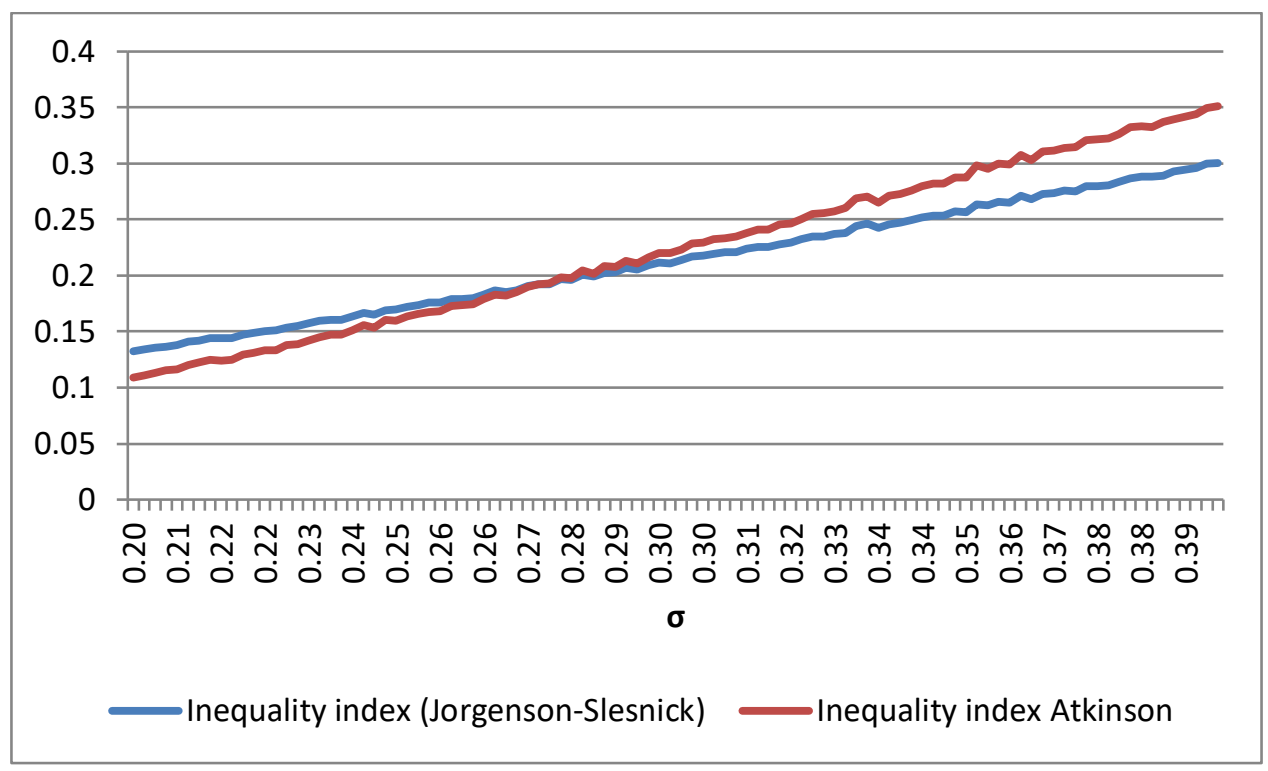

16 These benchmarks are $\log (\$ 39000)$ for the mean and a standard deviation of 0.3: when random draws from a lognormal distribution with these parameters are generated, these parameters approximate the empirical distribution quintiles of consumption expenditure per household equivalent member in recent years. For instance, for 2005 one obtains: Q1: 23224; Q2: 31516; Q3:39245, Q4:50793; Q5:80747 with values expressed in 2005 \$. 
On a more theoretical level, the Atkinson welfare function is separable and additive in its arguments, implying that the relative effects on welfare of changing the consumption of any two households is independent from the consumption of all other households. The Jorgenson-Slesnick function is not additively separable and hence, less stringent in this respect. We conclude that there is no single compelling argument in favour of one or the other specification: the Atkinson formula has simplicity to go for it and requires only the choice of one parameter but is theoretically more restrictive than the Jorgenson-Slesnick approach.

\section{References}

Abraham, Katharine G. (2014), "Expanded Measurement of Economic Activity: Progress and Prospects," in D.W. Jorgenson, S. Landefeld and P. Schreyer (eds.), Measuring Economic Sustainability and Progress: NBER and CRIW Studies in Income and Wealth, Vol 72; Chicago, University of Chicago Press; pp. 25-42.

Arrow, K. J. (1963), Social Choice and Individual Values, 2nd ed., New York: John Wiley.

Atkinson, Anthony B. (1970), “On the Measurement of Inequality,” Journal of Economic Theory, 2: $244-263$.

Barten A. P. (1964); "Family Composition, Prices and Expenditure Patterns"; in P. Hart, G. Mills and K. J. Whitaker (eds.); Econometric Analysis for National Economic Planning; 16th Symposium of the Colston Society; London, Butterworth, pp. 277-292.

Becker, Gary S. (1981); A Treatise on Family, Cambridge, MA; Harvard University Press.

Bennet, T. L. (1920); "The Theory of Measurement of Changes in Cost of Living"; Journal of the Royal Statistics Society 83: 455-462.

Blackorby, Charles and David Donaldson (1978); "Measures of Relative Equality and their Meaning in Terms of Social Welfare"; Journal of Economic Theory 18, pp. 59-80.

Broda C. and D. E. Weinstein (2008); Prices, Poverty and Inequality: Why Americans Are Better Off Than They Think; Washington D.C., AEI Press.

Budd, E. and D. Radner (1975); "The Bureau of Economic Analysis and Current Population Survey Size Distributions: Some Comparisons for 1964", in James D. Smith (ed.) The Personal Distribution of Income and Wealth, NBER and CRIW Studies in Income and Wealth, Vol. 39: New York: National Bureau of Economic Research; pp. 449-559. 
Chakravarty, Satya (2009); Inequality, Polarization and Poverty; New York: Springer.

Cowell, Frank; (2011); Measuring Inequality, 3rd ed.; Oxford: Oxford University Press.

Dalton, H. (1920); "The Measurement of the Inequality of Incomes"; Economics Journal 30; pp.348-61.

Deaton, A. (2005); "Measuring Poverty in a Growing World or (Measuring Growth in a Poor World)"; Review of Economic Statistics 87, no. 1: 1-19.

Deaton, A. and J. Muellbauer (1980); Economics and Consumer Behaviour, Cambridge, UK: Cambridge University Press.

Diewert, W.E. (1993); "Symmetric Means and Choice under Uncertainty" in Diewert, W.E. and A. Nakamura (eds.) Essays in Index Number Theory, Volume 1, pp. 355-433; Amsterdam: North Holland.

Diewert, W. Erwin (1985); "The Measurement of Waste and Welfare in Applied General Equilibrium Models"; in J. Piggott and J. Whalley (eds.); New Developments in Applied General Equilibrium Analysis, Cambridge, UK: Cambridge University Press.

Dutta, Bhaskar (2002); "Inequality, Poverty and Welfare" in K. J. Arrow, A. K. Sen, and K. Suzumura, Handbook of Social Choice and Welfare, Vol. 1; Amsterdam: Elsevier, pp. 597633.

Fesseau, Maryse, V. Bellamy and E. Raynaud (2009); "Inequality between households in the national accounts"; National Institute of Statistics and Economics Studies, INSEE Premier no $1265 A$.

Fesseau, Maryse and Maria Liviana Matteonetti (2013); "Distributional Measures Across Household Groups in a National Accounts Framework"; OECD Statistics Working Paper No. 53; Paris: OECD.

Fesseau, Maryse, Florence Wolff and Maria Liviana Mattonetti (2013), "A Cross-country Comparison of Household Income, Consumption and Wealth between Micro Sources and National Accounts Aggregates", OECD Statistics Working Paper, No. 52; Paris: OECD.

Financial Stability Board and International Monetary Fund (2009), The Financial Crisis and Information Gaps, Report the G20 Finance Ministers and Central Bank Governors, Washington, D.C., International Monetary Fund.

Fixler, Dennis and David S. Johnson (2014); "Accounting for the Distribution of Income in the US National Accounts"; in D.W. Jorgenson, S. Landefeld and P. Schreyer (eds.), Measuring Economic Sustainability and Progress: NBER and CRIW Studies in Income and Wealth, Vol. 72; Chicago, University of Chicago Press, pp. 213-244.

Fleurbaey, Marc (2009), "Beyond the GDP: The Quest for Measures of Social Welfare," Journal of Economic Literature, Vol. 47, No. 4, December, pp. 1029-1075. 
Fleurbaey, Marc and Didier Blanchet (2013); Beyond GDP: Measuring Welfare and Assessing Sustainability; Oxford: Oxford University Press.

Jorgenson, D. W. (1990), "Aggregate consumer behavior and the measurement of social welfare", Econometrica, Vol. 58, No. 5, September, pp. 1007-1040.

Jorgenson, D.W. and D.T. Slesnick (1983), "Individual and Social Cost of Living Indexes", in W.E. Diewert and C. Montmarquette (eds.), Price Level Measurement, pp. 241-323, Ottawa: Statistics Canada; pp. 241-323.

Jorgenson, D.W. and D.T. Slesnick (1987), "Aggregate Consumer Behavior and Household Equivalence Scales,” Journal of Business and Economic Statistics, 5(2): 219-232.

Jorgenson, D.W. and D.T. Slesnick (2014), "Measuring social welfare in the U.S. national accounts", in D.W. Jorgenson, S. Landefeld and P. Schreyer (eds.), Measuring Economic Sustainability and Progress: CRIW and NBER Studies in Income and Wealth, Vol. 72; pp. 43-88.

Kolm, S. C. (1969), "The Optimal Production of Social Justice", in: J. Margolis and H. Guitton (eds.) Public Economics, London: MacMillan; pp. 145-200.

Konüs, Alexander A. (1924); "The Problem of the True Index of Cost of Living" in The Economic Bulletin of the Institute of Economic Conjuncture (in Russian), No 9-10, pp. 6471; published in English in 1939 in Econometrica, Vol.7, pp. 10-29.

Lewbel, Arthur (1989), "Household Equivalence Scales and Welfare Comparisons", Journal of Public Economics 39 (3), pp. 377-391.

Lewbel, Arthur and Krishna Pendakur (2008); "Equivalence Scales"; in S.N. Durlauf and L.E. Blume (eds.) The New Palgrave Dictionary of Economics, 2nd edition, Volume 3;New York: Palgrave Macmillan; pp. 26-29.

Hagenaars, A., K. de Vos and M.A. Zaidi (1994), Poverty Statistics in the Late 1980s: Research Based on Micro-data, Luxembourg: Office for Official Publications of the European Communities.

Hardy, G.H., J.E. Littlewood and G. Polya (1934); Inequalities, Cambridge: Cambridge University Press.

May, K.O. (1952); “A Set of Independent Necessary and Sufficient Conditions for Simple Majority Decisions”, Econometrica, 20, pp. 680-684.

Malmquist, S. (1953); “Index Numbers and Indifference Surfaces”; Trabajos de Estadistica 4, pp. 209-242.

Meyer, B. and J. Sullivan (2011); "The Material Well-being of the Poor and Middle Class Since 1980"; AEI Working Paper no 2011-04. 
Muellbauer, J. (1977); "Testing the Barten Model of Household Composition Effects and the Costs for Children"; Economic Journal, vol. 87, No 347, September, pp. 460-487.

OECD (1982), The OECD List of Social Indicators, Paris: OECD

OECD (2008), Growing Unequal? Income Distribution and Poverty in OECD Countries, Paris:OECD.

OECD (2011), Divided We Stand - Why Inequality Keeps Rising, Paris: OECD.

OECD (2011); How's Life? Paris:OECD

OECD (2013a), OECD Framework for Statistics on the Distribution of Household Income, Consumption and Wealth. Paris: OECD.

OECD (2013b), OECD Guidelines for Micro Statistics on Household Wealth. Paris: OECD.

Pattanaik, Prasanta K. (2008); "Social Welfare Functions"; in S.N. Durlauf and L. E. Blume (eds.), The New Palgrave Dictionary of Economics, Vol. 7, pp. 662-666; New York: Palgrave Macmillan.

Pollak, Robert A. (1981), "The social cost of living index"; Journal of Public Economics 15: 311336.

Roberts, Kevin W.S (1980) "Possibility Theorems with Inter-personally Comparable Welfare Levels," Review of Economic Studies, 47:147, pp. 409-20.

Samuelson, Paul A. (1956); "Social Indifference Curves"; Quarterly Journal of Economics 70 (1): pp. 1-22.

Sen, A.K. (1973). On Economic Inequality, Clarendon Press, Oxford.

Slesnick, Daniel T. (1993); "Gaining Ground: Poverty in the Post-War United States”; Journal of Political Economy, volume 101, Issue 1, February, pp.1-38.

Slesnick, Daniel T. (1998); "Empirical Approaches to the Measurement of Welfare," Journal of Economic Literature, Vol. 36, No. 4, December, pp. 2108-2165.

Slesnick, Daniel T. (2001), Consumption and Social Welfare, Cambridge, Cambridge University Press.

Slutsky, Eugen (Evgeny) (1915), "Sulla theoria del bilancio del consumatore," Giornale degli Economisti (in Italian), 51(3): 1-26,

Stiglitz, J. E., A. Sen, and J-P. Fitoussi (2010), Mismeasuring Our Lives, Report by the

Commission on Measurement of Economic Performance and Social Progress, New York: The New Press. 
United Nations, et al. (2009), The System of National Accounts 2008, United Nations, New York. United Nations Economic Commission for Europe (2011); Canberra Group Handbook on Household Income Statistics; 2nd edition; Geneva: United Nations. 